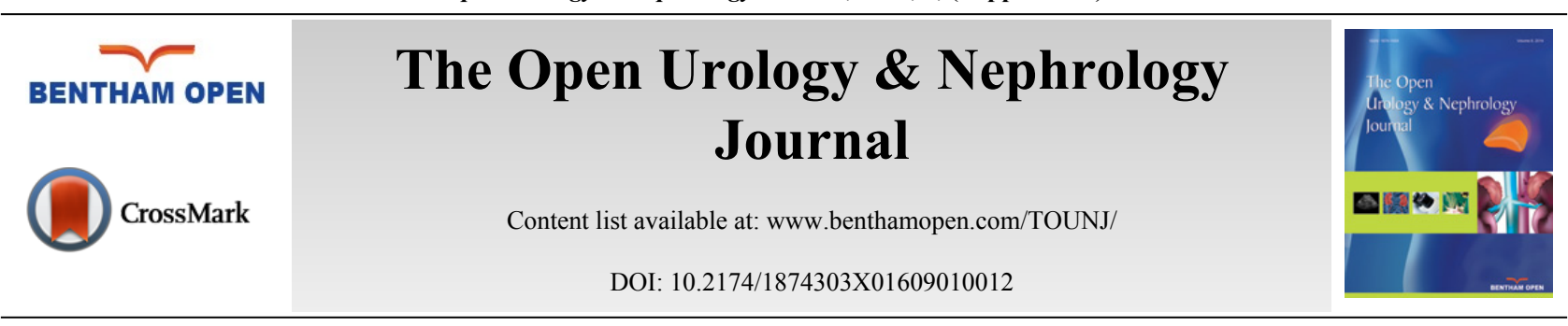

\title{
Kidney Disease and Gout: The Role of the Innate Immune System
}

\author{
William F. Finn ${ }^{*}$ \\ Chapel Hill, North Carolina, 27516, USA
}

\begin{abstract}
The clinical manifestations and consequence of acute and chronic gout are closely associated with the activation of the innate immune system, stimulation of the NLP3 inflammasome and secretion of interleukin-1 $\beta$ and interleukin-18 via caspace-1 activity. This leads to cytokine release and an inflammatory response. It is now clear that a similar involvement of the innate immune system occurs in many forms of acute and chronic kidney disease with accentuation of renal tubular injury and stimulation of tubulointerstitial fibrosis. The local and systemic activation of the innate immune system may help explain the close association of these conditions and provide a target for therapeutic interdiction.
\end{abstract}

Keywords: Gout, inflammasomes, innate immune system, interleukin-1 $\beta$, kidney disease.

\section{INTRODUCTION}

The relationship between hyperuricemia, gout and kidney disease has been the source of interest for decades. In recent years it has become of increasing concern as the prevalence of both gout [1] and chronic kidney disease [2] increases. Although the reasons for these increases may differ, there continues to be considerable epidemiological data to suggest that the close association of gout with chronic kidney disease is not by chance alone. In almost all forms or acute and chronic renal disease - regardless of the etiology of the primary disease - there is a significant tubulointerstitial involvement. The anatomical changes are accompanied by a variety of functional tubular defects, not the least of which are the effects on the sophisticated group of urate transporters contained in renal tubular cells that are critical in the maintenance of homeostasis.

While the influence of chronic kidney disease on urate excretion is understandable, not so is the influence of urate particularly in the subject with gout - on kidney disease. Whether an instigator or promoter, the effects of urate on the kidney have gone through a number of reiterations only to fail to reach a consensus. Certainly there are isolated cases of cases of renal tophi. However, the general idea of a specific nephropathy related to hyperuricemia and gout has been dismissed by some [3]. On the other hand, the demonstration that the appearance of hyperuricemia predicts the later development of chronic kidney disease [4] has kept the issue alive.

In part, the conundrum persists because of a lack of a unifying hypothesis that can explain common pathophysiology. Nonetheless, there is one feature of hyperuricemia and gout and chronic kidney disease that is shared. That is, both conditions have prominent inflammatory components. This is most obvious in dealing with acute and chronic gout where the clinical manifestations are intimately associated with activation of the innate immune system. While it is true that the adaptive immune system is involved in certain forms of kidney disease, this does not preclude giving consideration to the role of the innate immune system in the onset and progression of kidney disease. Indeed, the classical understanding that the innate immune system is primarily designed to abort external pathogenic attacks has been contemporized by the realization that the innate immune system also responds to internal non-pathogenic or sterile injury. Of note is the suggestion that the chronic, low-grade, systemic inflammatory response that occurs in another rheumatologic disease (i.e. rheumatoid arthritis) is central to the accelerated atherogenesis and high rate of cardiovascular disease present in this condition [5].

\footnotetext{
* Address correspondence to this author at the 1820 McLennans Farm Road, Chapel Hill, North Carolina, 27516, USA; E-mail: wffinn@med.unc.edu
} 
By extension, this raises the possibility that the innate immune responses that are triggered by uric acid/mono-sodium urate (UA) could contribute to the comorbidities of gout including chronic renal disease [6]. It is possible, this helps to explain the accelerant effect each appears to have on the other (Fig. 1).

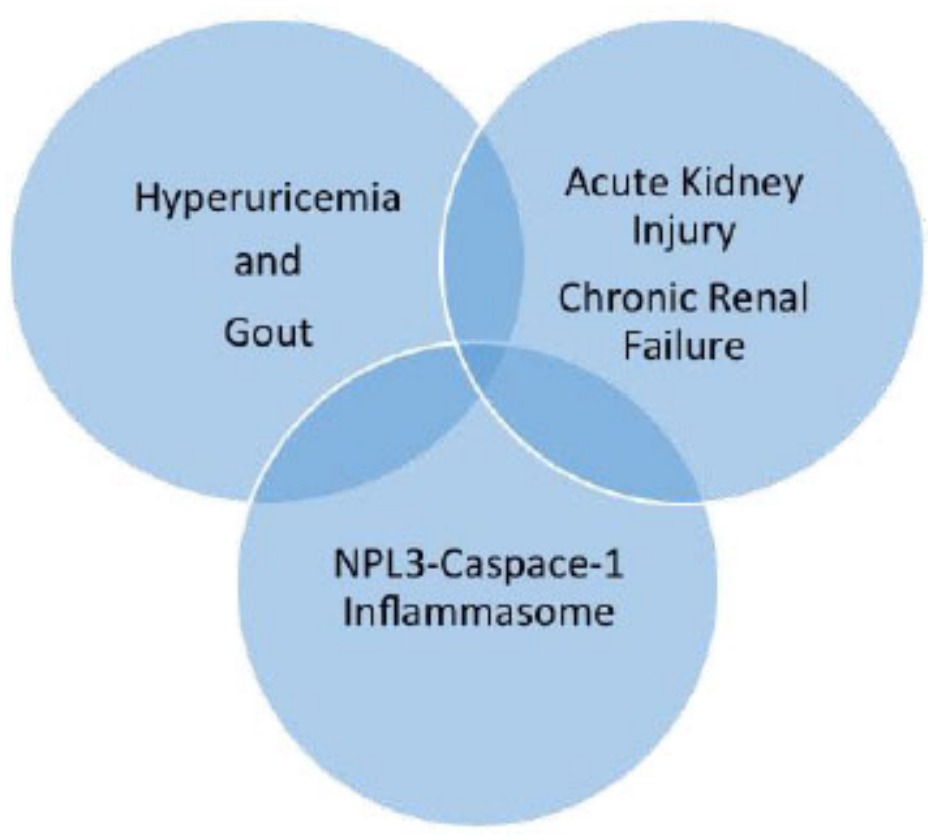

Fig. (1). Hyperuricemia and gout are commonly associated with both acute chronic kidney disease. Common to both conditions is stimulation of the innate immune system with activation of the NLRP3 inflammasone, generation of IL-1 $\beta$ and IL-18, and release of cytokines and chemokines.

\section{URIC ACID AND THE KIDNEY}

What then is the association of hyperuricemia and gout with kidney disease? To begin it should be recognized that neither term describes a specific entity. Hyperuricemia and gout may be hereditary or acquired, related to over production or under excretion of uric acid, or influenced by drugs, environmental agents or concomitant disease activity. Moreover, the disconnection between asymptomatic hyperuricemia and clinical acute and chronic gout offers additional complexity. In similar fashion, the nature of the renal diseases associated with hyperuricemia and gout range from renal stone formation and occasional renal tophi [7] to overt renal parenchymal lesions with varying degrees of arteriolar sclerosis, glomerularsclerosis and interstitial fibrosis [4, 7 - 10].

The daily excretion of UA occurs through both the gastrointestinal tract and the kidneys. The gastrointestinal tract accounts for only $20-30 \%$ of the total while the kidney is responsible for the larger amount. UA is freely filtered through the glomerulus. Because of substantial tubular reabsorption, the fractional excretion of UA is usually not more than $10 \%$. That is, $90 \%$ of the total UA filtered is reabsorbed. The system responsible for the real tubular handling of UA has collectively come to be known as the UA transportasome. UA transport in the renal proximal tubule involves a sophisticated group of transporters that control the secretion and reabsorption of UA from and into the tubular lumen. Each process requires the transcellular movement of UA across the apical and basolateral membranes. The balance between these two processes determines the amount of UA that ultimately appear in the urine. The transporters include the urate anion transporter 1 (URATE-1), the glucose transporter type 9 (GLUT-9), the ATP-binding cassette subfamily (BCRP), various organic anion transporters (OAT1, OAT3, OAT4, ORCTL-3), the multidrug resistant protein 4 (MRP4), the type 1 phosphate transporter (NPT4), the sodium phosphate transporter (NPT4) and the sodium-coupled monocarboxylate transporter 1 and 2 (SMCT1, SMCT2) [11, 12].

The $\mathrm{pKa}$ of uric acid is approximately 5.3. At the physiologic $\mathrm{pH}$ of 7.4, the equilibrium between the undissociated acid and the salt form is significantly shifted towards the more soluble salt form as monosodium urate. Supersaturation may occur at concentrations $>6.8 \mathrm{mg} / \mathrm{dL}$, favoring the tissue deposition of monosodium urate crystals (MSU). There are two features of the intrarenal environment that are of note. First the urine $\mathrm{pH}$ may be as low as 4.4 compared to the plasma $\mathrm{pH}$ of 7.4. This is equivalent to a hydrogen ion gradient of 1000:1. At this $\mathrm{pH}$, the equilibrium shifts from 
monosodium urate to less soluble undissociated uric acid. Second, due to the countercurrent multiplication system, the renal concentration of UA in the renal papilla and collecting ducts may easily exceed the solubility level. These physiological considerations favoring crystal formation provided the basis for the concept "gouty nephropathy".

When it was realized that intrarenal UA crystals could be found without associated pathological changes or were located in locations apart from the areas of renal scarring, the designation of "gouty nephropathy" was questioned [13]. While it is clear that chronic kidney disease contributes to the progression of hyperuricemia and gout, the question of whether hyperuricemia and gout independently contribute to the onset and progression of chronic kidney disease is the issue $[14,15]$. This notion persists because of several studies that have identified elevated levels of serum UA as an independent risk factor for the onset and progression of chronic kidney disease [16 - 20]. This is true for both men and women [21].

To explain this association, mechanisms of injury have been proposed that do not depend on the physical presence of uric acid in the kidney. These include the hyperuricemic induction of renal afferent arteriosclerosis [22], abnormalities in endothelial dysfunction caused by impaired nitric oxide production, increased oxidative stress, platelet activation, vascular smooth muscle proliferation, and stimulation of proinflammatory cytokines [23]. Whatever the cause, the preponderance of data support the hypothesis that UA is a cause or exacerbating factor of progressive kidney disease [24].

\section{INNATE IMMUNE SYSTEM}

The human innate immune system is a critical regulator of the inflammatory response - serving as the initial and immediate immune defense against pathogens and various stress factors released by damaged tissue. There is a considerable amount of information on the role played by the innate immune system in the clinical manifestations and consequences of gout. In addition, there is increasing evidence that the innate immune system is an important determinant of the response of the kidneys to acute and chronic renal injury. With the incompletely understood association between gout and kidney disease, it is reasonable to explore the possibility that activation of the innate immune system - common to both - may help explain this association.

Protection from infection is accomplished by the recognition on bacteria, virus or fungi of various molecular patterns (pathogen-associated molecular patterns or PAMPs) that coincide with receptors on the responding cells (pattern recognition receptors of PRRs). These PRRs are the foundation of the innate immune system [25]. Examples of PAMPs include bacterial cell membrane lipopolysaccharides, nucleic acids associated with viruses and complex carbohydrates present in fungal cell walls. Important to our discussion is the ability of innate immune system to also respond to non-microbial signals that are considered dangerous. These are generally but not exclusively intracellular molecules liberated from injured cells (damage-associated molecular patterns or DAMPs). Protein DAMPs include intracellular proteins and proteins derived from the extracellular matrix that are generated following tissue injury. Nonprotein DAMPs include ATP, uric acid, heparin sulfate and DNA. The cells that recognize PAMPs and DAMPs include cells residing in tissues, such as macrophages, fibroblasts, mast cells, and dendritic cells, as well as circulating leukocytes, including monocytes and neutrophils.

Several classes of PRRs have been described. They include cell surface or endosomal Toll-like receptors (TLRs). These initiate the immune response following recognition of either PAMPs present in microbial molecules or DAMPs released by damaged cells. In a different category are the cytosolic retinoic acid-inducible gene -1 (RIG-1-like receptors or RLRs) that are involved in the recognition of viral RNA. The C-type lectin receptors (CLRs) are both transmembrane and soluble and able to recognize carbohydrates on microbial cells. The AIM2-like receptors are important in the sensing of bacterial and viral pathogens and are both necessary and sufficient for inflammasome activation in response to cytoplasmic DNA. There is one family of intracellular receptors that is of particular interest. This is the cytosolic nucleotide-binding oligomerization domain receptors or NOD-like receptors (NLRs) that are sensors of both PAMPs and DAMPs. They provide a second line of defense against pathogens that have gained entry within cells and very importantly deal with the consequences of non-pathogenic, sterile injury.

\section{INFLAMMASOMES}

The NLR family contains a number of subfamilies, several of which are capable of forming multiprotein inflammasomes. These complexes survey intracellular compartments for the presence of pathogenic microorganisms and various damage-associated molecular patterns that may include various sterile stressors that include products of injured or dying cells and are thus critical in the host response [26]. Several inflammasome complexes have been identified. Each is 
typically named after the NLR protein that initiates signaling (i.e. NLRP1, NLRC4, NLRP3). The best studied and most relevant is the NLRP3 inflammasome which is expressed in a number of cells including monocytes, macrophages, neutrophiles and dendritic cells and is closely involved in the response to sterile, non-pathogen related signals. The inflammasome consists of three components: a sensor, an adapter protein ASC (Apoptosis-associated Speck-like protein containing a CARD) and caspace-1. The sensor or pattern recognition receptor is the NLRP molecule. The adapter protein acts in the assembly of the inflammasome, linking NLRP to pro-caspase-1 leading to the autocatalysis and activation of caspace-1. Caspace-1 - formally referred to as interleukin-1 converting enzyme - proteolytic cleaves other proteins, such as the precursor forms of the inflammatory cytokines interleukin-1 $\beta$ (IL-1 $\beta$ ) and interleukin-18 (IL-18), into active mature peptides [27].

IL-1 $\beta$ and IL-18 are secreted locally but circulate systemically where they play critical roles as mediators of generalized acute and chronic inflammation. Both are involved in a variety of cellular activities, including cell proliferation and differentiation [28]. By subsequently activating cytokine-inducing effects on cells of the innate immune system they have the capacity to relay or amplify the initial danger message and to extend the inflammatory response to other areas. The stimulation of the cellular response serves as a crucial link in translating innate immune responses into the appropriate adaptive immune response. In chronic inflammatory conditions, the overall process, while serving a necessary function, may be responsible for varying degrees of tissue dysfunction and destruction [29, 30] such as the erosive arthritis of gout and the interstitial fibrosis in many forms of chronic kidney disease.

To minimize this possibility, there are mechanisms to abrogate the inflammatory response. Under ordinary circumstances activation of the inflammasomes culminates in the resolution of infection and the onset of tissue repair. In some cases, however, the inflammatory response persists with the potential for adding to the initial tissue injury. Deregulated innate immunity is not uncommon and is a contributing feature in a range of progressive renal diseases [31] marked by prolonged increase in IL-1 $\beta$ production and signaling [32]. The ongoing inflammation may relate to a failure of the caspase- 1 inflammasome to control the processing of the IL- $1 \beta$ precursor. Also, IL- $1 \beta$ may drive its own synthesis by promoting persistent inflammasome activation [33]. In either case, excessive or prolonged IL-1 $\beta$ generation and the downstream effect can cause widespread tissue damage [34]. Thus, when the innate immune system is permanently stimulated, phagocytosis, activation and regulation of the inflammasome and activity of cytokines, chemokines may be locally and systemically injurious [35].

\section{INNATE IMMUNE SYSTEM AND GOUT}

The inflammatory manifestations of gout and other conditions associated with crystal deposition are intimately related to the consequence of NLRP3-mediated IL-1 $\beta$ secretion as a fundamental pathologic mechanism. With the deposition of MSU crystals, resident cells within tissues such as macrophages or monocytes, respond by the phagocytosis and internalization of crystals by monocytes. MSU crystals disrupt lysosomes and in this way activate the NALP3 inflammasome. The NALP3 protein activation leads to the maturation of pro-IL-1 $\beta$ into its biologically active form, IL-1 $\beta$. The subsequent recruitment of inflammatory leukocytes to the site accounts for the subsequent release of inflammatory mediators and the recognized inflammatory manifestations of acute gout [36]. Binding of IL-1 $\beta$ to its target cells activates inflammatory transcription factors such as NF-k $\beta$ thereby promoting the production and release of inflammatory mediators such as neutrophil-recruiting chemokines. The influx of neutrophils into the joint with the prospect of chronic inflammation and joint destruction is the signature pathogenic hallmark of gout. The central role of IL-1 $\beta$ in this process is supported by the ability to achieve a rapid and sustained reduction in disease severity by the use of IL-1 $\beta$ blocking agents [37]. Success is such that this class of drugs has potential therapeutic as a treatment for gout [38].

\section{INNATE IMMUNE SYSTEM AND KIDNEY DISEASE}

There is growing evidence that the innate immune system is involved in the initiation and progression of various forms of both acute and chronic kidney disease. There have been a number of recent reviews on the subjects of the innate immune system and inflammasome activation in kidney disease [39 - 44]. These reviews have considered in detail the experimental and clinical evidence that supports a prominent role of the innate immune system in a broad spectrum of renal disease ranging from acute kidney injury and progressive chronic kidney disease. The common theme is that the kidneys possess all of the necessary components to activate the innate immune system and in particular, NLRP3 inflammasome activity in both resident and infiltrating cells [43 - 45]. 


\section{Lessons from Oxalate Nephropathy}

Oxalate, an end product of metabolism, is a small molecule that is readily filtered through the glomerulus. In the setting of hyperoxaluria the urine eventually becomes supersaturated with calcium oxalate. Crystals can formation within tubular cells, in the tubular lumen and in the renal pelvis, resulting in tubular epithelial cell injury, tubular obstruction and stones formation and eliciting an inflammatory response in the surrounding interstitium. Studies in mice $[46,47]$ have shown that calcium oxalate crystals activate renal dendritic cells, increase expression of the NLP3 inflammasome and the production of IL-1 $\beta$. However, in mice deficient in NLRP3, caspase-1, IL-1 $\beta$ or IL-18 the intrarenal inflammation, tubular damage, and renal dysfunction could be abrogated. Also, the nephropathy could be attenuated by dendritic cell depletion, ATP depletion, or therapeutic IL-1 antagonism. In these studies, calcium oxalate crystals triggered the NLRP3-caspase-1-IL-1 $\beta$ axis in intrarenal mononuclear phagocytes and directly damaged tubular epithelial cells [46] and progressive renal failure [47]. Thus, prolonged activation of the intrarenal inflammasome is responsible for the loss of kidney function in oxalate crystal nephropathy and raises the possibility that this mechanism contributes to other forms of chronic kidney disease [48].

\section{The Role of the Inflammasome in Kidney Diseases}

\section{Acute Kidney Injury:}

Renal tubular epithelial cells are highly susceptible to injury from nephrotoxic agents and/or significant reductions in renal blood flow. The extent of recovery from acute injury depends not only on the severity of the initial insult but also to the nature of the subsequent inflammatory response. Indeed, inflammation is an important contributor to the development of renal failure. Injured tubular epithelial cells release various damage-associated molecular patterns that activate receptors on renal parenchymal and dendritic cells. These 'danger signals' may include but are not limited to reactive oxygen species, extracellular ATP and uric acid, nucleic acids, and various extracellular matrix components. A number of pattern recognition receptors including Toll-like receptors and NOD-like receptors are constitutively expressed in many parts of the kidney.

Information concerning the toll-like receptors and acute kidney injury is limited with exception of their involvement on ischemia-reperfusion injury where they have been implicated in the recognition of endogenous molecules released during cellular necrosis and may be critical regulators of sterile inflammation and injury. The toll-like receptors are more widely described as contributing to activation of the complement system and recruitment of immune cells in response to microbial stimuli [49].

There is more information concerning the NOD-like receptors and their involvement in acute sterile inflammation. For example, ATP released from mitochondria of necrotic cells is capable of starting the sequence of NLRP3 activation, IL-1 $\beta$ and IL-18 release and an inflammatory response which is amplified by infiltrating monocyte/macrophage and neutrophils. Once initiated, the inflammatory response may be disproportionate to the severity of the initial injury with the potential to worsen the kidney injury [41] and effect recovery. The result may be persistent inflammation, failure of injured cells to regenerate, tubular atrophy, and interstitial fibrosis [50].

\section{Chronic Kidney Disease:}

In almost all forms of renal disease the rate of progression and the ultimate prognosis are dictated by the extent of involvement of the tubulointerstitial compartment. Interstitial inflammation is such an important complication of most glomerular diseases that it is considered to be an independent predictor of disease progression in as much as irreversible kidney damage may occur when inflammation spreads to the tubulointerstitium. As is generally the case, this inflammation is initiated by soluble mediators that are liberated in response to local cell stress and tissue injury. This leads to cytokine expression and the subsequent infiltration into the interstitium of mononuclear cells. Glomerular cells (mesangial cells or podocytes) have the capacity to activate the NLRP3 inflammasome and to initiate inflammatory pathways that secondarily involve the tubulointerstitium. Alternatively or in addition, tubulointerstitial injury may occur as a consequence of alterations in peritubular capillary blood flow and downstream ischemia. Lastly, the tubulointerstitial injury could be a result of a primary pathogenic process. In each case, the result is NLRP3 inflammasome activation. The cells involved include cells in residence (e.g. tubulointerstitial and dendritic cells) or infiltrating inflammatory cells (e.g. monocytes/macrophages) [41]. Once again, it is important to point out that unresolved inflammation promotes progressive renal fibrosis through activation of intrinsic renal cells with the consequent production and release of profibrotic cytokines and growth factors that drive the fibrotic process which can 
culminate in end-stage renal disease [51].

There are a number of clinical observations that support the notion that the activity of the NHLP3 inflammasome may be relevant to a wide variety of glomerular and tubulointerstitial diseases [41]. These range from studies on human renal biopsy material to the analysis of serum and urine samples for the presence of inflammatory biomarkers. In many cases, a correlation can be made between disease activity and the degree of activation of the innate immune system. To mention a few, in subjects with chronic kidney disease levels of mRNA encoding NLRP3 correlate with renal function [52]. In tissue from human renal biopsies, a wide variety of nondiabetic kidney diseases exhibited increased expression of NLRP3 mRNA, which correlated with renal function [53]. It has been suggested that activation of the NLRP3 inflammasome and secretion of IL-1 $\beta$ and IL-18 family of cytokines causes the development of tubulointerstitial inflammation in subjects with diabetic nephropathy [54]. Similarly, in both proximal and distal tubules of human kidney biopsies in diabetic patients the severity of proteinuria correlates wells with the protein expression of caspase- 1 , IL- $1 \beta$ and IL-18 and evidence has been presented that albuminuria may itself be responsible for inflammasome activation in the renal tubule and thus contribute to the progressive tubulointerstitial fibrosis [55] and the endothelial dysfunction associated with chronic kidney disease [56]. IL-17 and IL- 18 are detectable in the urine of patients with the nephrotic syndrome and the levels correlate with the disease activity $[57,58]$. Increased serum levels of IL-18 has been found in the serum of patients with chronic kidney disease [59].

In addition to the response to kidney-specific DAMPs, inflammasome within the kidney can be induced by proinflammatory cytokines emanating from extra-renal sites [39]. That is, cytokines released by circulating leukocytes may act in a systemic, paracrine, or an autocrine fashion [60]. This is an important - if not critical - consideration for it has the potential of linking external inflammatory conditions to intrinsic renal disease.

\section{SUMMARY}

The possibility that the chronic inflammation associated with gout has a detrimental effect on the kidney and that this occurs as a consequence of activation of the innate immune system seems reasonable. There are several studies that support the possibility that reductions in the serum UA concentration with the xanthine oxidase inhibitor allopurinol may improve or stabilize renal function [61 - 76]. Several of these studies [61 - 68] have been the subject of a metaanalysis [69] with the conclusion that UA-lowering therapy with allopurinol may retard the progression of CKD but that the studies are not sufficiently powered to properly evaluate the benefits and risks of UA-lowering therapy in CKD. Other clinical observational studies suggest an association between serum UA levels and renal outcomes [70 - 73] including those receiving the xanthine oxidase inhibitor febuxostat [72].

To a considerable extent, the subjects included in these studies have had years of exposure to elevate serum levels of UA and likely have had a significant increase in the total body burden of UA. This is certainly the case in those with tophaceous gout. It may be that the indeterminate nature of studies that had concentrated only on lowering serum UA levels may not have effectively removed the potential inflammatory stimulus of UA retained in tissues. This does not necessarily disagree with the experimental and clinical studies that relate an elevated level of UA - even without the deposition of UA crystals - to the onset or progression of kidney disease [74].

The Interruption of the inflammatory pathway by the use of interleukin-1 receptor antagonist has been shown to be an effective treatment of a broad spectrum of inflammatory syndromes [75] including gout [76]. Several primary renal diseases and systemic diseases affecting the kidney are associated with NLRP3 inflammasome and IL-1 $\beta$ and IL-18 activation and as a result, therapeutic agents targeting this pathway may have the potential for controlling chronic inflammation in both the patient with gout and chronic renal disease [77, 78].

\section{CONFLICT OF INTEREST}

Consultant Takeda Pharmaceuticals; Consultant Ardea Biosciences.

\section{ACKNOWLEDGEMENTS}

Declared none.

\section{REFERENCES}

[1] Zhu Y, Pandya BJ, Choi HK. Prevalence of gout and hyperuricemia in the US general population: the National Health and Nutrition Examination Survey 2007-2008. Arthritis Rheum 2011; 63(10): 3136-41. 
[http://dx.doi.org/10.1002/art.30520] [PMID: 21800283]

[2] Coresh J, Selvin E, Stevens LA, et al. Prevalence of chronic kidney disease in the United States. JAMA 2007; 298(17): 2038-47. [http://dx.doi.org/10.1001/jama.298.17.2038] [PMID: 17986697]

[3] Moe OW. Posing the question again: does chronic uric acid nephropathy exist? J Am Soc Nephrol 2010; 21 (3): 395-7. [http://dx.doi.org/10.1681/ASN.2008101115] [PMID: 19729442]

[4] Obermayr RP, Temml C, Gutjahr G, Knechtelsdorfer M, Oberbauer R, Klauser-Braun R. Elevated uric acid increases the risk for kidney disease. J Am Soc Nephrol 2008; 19(12): 2407-13. [http://dx.doi.org/10.1681/ASN.2008010080] [PMID: 18799720]

[5] Sattar N, McCarey DW, Capell H, McInnes IB. Explaining how "high-grade" systemic inflammation accelerates vascular risk in rheumatoid arthritis. Circulation 2003; 108(24): 2957-63.

[http://dx.doi.org/10.1161/01.CIR.0000099844.31524.05] [PMID: 14676136]

[6] Rock KL, Kataoka H, Lai JJ. Uric acid as a danger signal in gout and its comorbidities. Nat Rev Rheumatol 2013; 9(1): 13-23. [http://dx.doi.org/10.1038/nrrheum.2012.143] [PMID: 22945591]

[7] Mehta TH, Goldfarb DS. Uric acid stones and hyperuricosuria. Adv Chronic Kidney Dis 2012; 19(6): 413-8. [http://dx.doi.org/10.1053/j.ackd.2012.07.014] [PMID: 23089277]

[8] Talbott JH, Terplan KL. The kidney in gout. Medicine (Baltimore) 1960; 39: 405-67. [http://dx.doi.org/10.1097/00005792-196012000-00001] [PMID: 13775026]

[9] Barlow KA, Beilin LJ. Renal disease in primary gout. Q J Med 1968; 37(145): 79-96. [PMID: 5657765]

[10] Gonick HC, Rubini ME, Gleason IO, Sommers SC. The Renal Lesion in Gout. Ann Intern Med 1965; 62: 667-74. [http://dx.doi.org/10.7326/0003-4819-62-4-667] [PMID: 14274831]

[11] Reginato AM, Mount DB, Yang I, Choi HK. The genetics of hyperuricaemia and gout. Nat Rev Rheumatol 2012; 8(10): 610-21. [http://dx.doi.org/10.1038/nrrheum.2012.144] [PMID: 22945592]

[12] George RL, Keenan RT, Keenan RT. Genetics of hyperuricemia and gout: implications for the present and future. Curr Rheumatol Rep 2013; 15(2): 309-20.

[http://dx.doi.org/10.1007/s11926-012-0309-8] [PMID: 23307580]

[13] Linnane JW, Burry AF, Emmerson BT. Urate deposits in the renal medulla. Prevalence and associations. Nephron 1981; 29(5-6): 216-22. [http://dx.doi.org/10.1159/000182373] [PMID: 7322250]

[14] Karis E, Crittenden DB, Pillinger MH. Hyperuricemia, gout, and related comorbidities: cause and effect on a two-way street. South Med J 2014; 107(4): 235-41. [http://dx.doi.org/10.1097/SMJ.0000000000000082] [PMID: 24937517]

[15] Johnson RJ, Nakagawa T, Jalal D, Sánchez-Lozada LG, Kang DH, Ritz E. Uric acid and chronic kidney disease: which is chasing which? Nephrol Dial Transplant 2013; 28(9): 2221-8. [http://dx.doi.org/10.1093/ndt/gft029] [PMID: 23543594]

[16] Satirapoj B, Supasyndh O, Chaiprasert A, et al. Relationship between serum uric acid levels with chronic kidney disease in a Southeast Asian population. Nephrology (Carlton) 2010; 15(2): 253-8. [http://dx.doi.org/10.1111/j.1440-1797.2009.01179.x] [PMID: 20470288]

[17] Domrongkitchaiporn S, Sritara P, Kitiyakara C, et al. Risk factors for development of decreased kidney function in a southeast Asian population: a 12-year cohort study. J Am Soc Nephrol 2005; 16(3): 791-9. [http://dx.doi.org/10.1681/ASN.2004030208] [PMID: 15677313]

[18] Obermayr RP, Temml C, Knechtelsdorfer M, et al. Predictors of new-onset decline in kidney function in a general middle-european population. Nephrol Dial Transplant 2008; 23(4): 1265-73. [http://dx.doi.org/10.1093/ndt/gfm790] [PMID: 18039642]

[19] Syrjänen J, Mustonen J, Pasternack A. Hypertriglyceridaemia and hyperuricaemia are risk factors for progression of IgA nephropathy. Nephrol Dial Transplant 2000; 15(1): 34-42. [http://dx.doi.org/10.1093/ndt/15.1.34] [PMID: 10607765]

[20] Iseki K, Oshiro S, Tozawa M, Iseki C, Ikemiya Y, Takishita S. Significance of hyperuricemia on the early detection of renal failure in a cohort of screened subjects. Hypertens Res 2001; 24(6): 691-7. [http://dx.doi.org/10.1291/hypres.24.691] [PMID: 11768729]

[21] Kanda E, Muneyuki T, Kanno Y, Suwa K, Nakajima K. Uric acid level has a U-shaped association with loss of kidney function in healthy people: a prospective cohort study. PLoS One 2015; 10(2): e0118031. [http://dx.doi.org/10.1371/journal.pone.0118031] [PMID: 25658588]

[22] Kang DH, Nakagawa T, Feng L, et al. A role for uric acid in the progression of renal disease. J Am Soc Nephrol 2002; $13(12)$ : $2888-97$. [http://dx.doi.org/10.1097/01.ASN.0000034910.58454.FD] [PMID: 12444207]

[23] Filiopoulos V, Hadjiyannakos D, Vlassopoulos D. New insights into uric acid effects on the progression and prognosis of chronic kidney disease. Ren Fail 2012; 34(4): 510-20. 
[http://dx.doi.org/10.3109/0886022X.2011.653753] [PMID: 22260409]

[24] Feig DI. Serum uric acid and the risk of hypertension and chronic kidney disease. Curr Opin Rheumatol 2014; 26(2): 176-85. [http://dx.doi.org/10.1097/BOR.0000000000000033] [PMID: 24419747]

[25] Lamkanfi M, Dixit VM. Inflammasomes and their roles in health and disease. Annu Rev Cell Dev Biol 2012; 28: 137-61. [http://dx.doi.org/10.1146/annurev-cellbio-101011-155745] [PMID: 22974247]

[26] Henao-Mejia J, Elinav E, Strowig T, Flavell RA. Inflammasomes: far beyond inflammation. Nat Immunol 2012; 13(4): 321-4. [http://dx.doi.org/10.1038/ni.2257] [PMID: 22430784]

[27] Latz E, Xiao TS, Stutz A. Activation and regulation of the inflammasomes. Nat Rev Immunol 2013; 13(6): 397-411. [http://dx.doi.org/10.1038/nri3452] [PMID: 23702978]

[28] Garlanda C, Dinarello CA, Mantovani A. The interleukin-1 family: back to the future. Immunity 2013; 39(6): 1003-18. [http://dx.doi.org/10.1016/j.immuni.2013.11.010] [PMID: 24332029]

[29] Ozaki E, Campbell M, Doyle SL. Targeting the NLRP3 inflammasome in chronic inflammatory diseases: current perspectives. J Inflamm Res 2015; 8: 15-27.

[PMID: 25653548]

[30] Sims JE, Smith DE. The IL-1 family: regulators of immunity. Nat Rev Immunol 2010; 10(2): 89-102. [http://dx.doi.org/10.1038/nri2691] [PMID: 20081871]

[31] Hato T, Dagher PC. How the immune system senses trouble and causes trouble. Clin J Am Soc Nephrol 2015; 10(8): 1459-69. [http://dx.doi.org/10.2215/CJN.04680514] [PMID: 25414319]

[32] Lukens JR, Dixit VD, Kanneganti TD. Inflammasome activation in obesity-related inflammatory diseases and autoimmunity. Discov Med 2011; 12(62): 65-74.

[PMID: 21794210]

[33] Gattorno M, Tassi S, Carta S, et al. Pattern of interleukin-1beta secretion in response to lipopolysaccharide and ATP before and after interleukin-1 blockade in patients with CIAS1 mutations. Arthritis Rheum 2007; 56(9): 3138-48. [http://dx.doi.org/10.1002/art.22842] [PMID: 17763411]

[34] Abderrazak A, Syrovets T, Couchie D, et al. NLRP3 inflammasome: from a danger signal sensor to a regulatory node of oxidative stress and inflammatory diseases. Redox Biol 2015; 4: 296-307. [http://dx.doi.org/10.1016/j.redox.2015.01.008] [PMID: 25625584]

[35] Blach-Olszewska Z, Leszek J. Mechanisms of over-activated innate immune system regulation in autoimmune and neurodegenerative disorders. Neuropsychiatr Dis Treat 2007; 3(3): 365-72. [PMID: 19300567]

[36] Busso N, So A. Mechanisms of inflammation in gout. Arthritis Res Ther 2010; 12(2): 206-13. [http://dx.doi.org/10.1186/ar2952] [PMID: 20441605]

[37] Dinarello CA, van der Meer JW. Treating inflammation by blocking interleukin-1 in humans. Semin Immunol 2013; 25(6): 469-84. [http://dx.doi.org/10.1016/j.smim.2013.10.008] [PMID: 24275598]

[38] Sivera F, Wechalekar MD, Andrés M, Buchbinder R, Carmona L. Interleukin-1 inhibitors for acute gout. Cochrane Database Syst Rev 2014; 9: CD009993.

[http://dx.doi.org/10.1002/14651858.CD009993.pub2]

[39] Anders H-J, Muruve DA. The inflammasomes in kidney disease. J Am Soc Nephrol 2011; 22(6): 1007-18. [http://dx.doi.org/10.1681/ASN.2010080798] [PMID: 21566058]

[40] Chang A, Ko K, Clark MR. The emerging role of the inflammasome in kidney diseases. Curr Opin Nephrol Hypertens 2014; 23(3): $204-10$. [http://dx.doi.org/10.1097/01.mnh.0000444814.49755.90] [PMID: 24685591]

[41] Gonçalves GM, Castoldi A, Braga TT, Câmara NO. New roles for innate immune response in acute and chronic kidney injuries. Scand J Immunol 2011; 73(5): 428-35.

[http://dx.doi.org/10.1111/j.1365-3083.2011.02523.x] [PMID: 21272051]

[42] Imig JD, Ryan MJ. Immune and inflammatory role in renal disease. Compr Physiol 2013; 3(2): 957-76. [PMID: 23720336]

[43] Jang HR, Rabb H. Immune cells in experimental acute kidney injury. Nat Rev Nephrol 2015; 11(2): 88-101. [http://dx.doi.org/10.1038/nrneph.2014.180] [PMID: 25331787]

[44] Leemans JC, Kors L, Anders H-J, Florquin S. Pattern recognition receptors and the inflammasome in kidney disease. Nat Rev Nephrol 2014; 10(7): 398-414.

[http://dx.doi.org/10.1038/nrneph.2014.91] [PMID: 24890433]

[45] Lorenz G, Darisipudi MN, Anders H-J. Canonical and non-canonical effects of the NLRP3 inflammasome in kidney inflammation and fibrosis. Nephrol Dial Transplant 2014; 29(1): 41-8. [http://dx.doi.org/10.1093/ndt/gft332] [PMID: 24026244]

[46] Mulay SR, Kulkarni OP, Rupanagudi KV, et al. Calcium oxalate crystals induce renal inflammation by NLRP3-mediated IL-1 $\beta$ secretion. J Clin Invest 2013; 123(1): 236-46. 
[http://dx.doi.org/10.1172/JCI63679] [PMID: 23221343]

[47] Knauf F, Asplin JR, Granja I, et al. NALP3-mediated inflammation is a principal cause of progressive renal failure in oxalate nephropathy. Kidney Int 2013; 84(5): 895-901.

[http://dx.doi.org/10.1038/ki.2013.207] [PMID: 23739234]

[48] Kurts C. A crystal-clear mechanism of chronic kidney disease. Kidney Int 2013; 84(5): 859-61. [http://dx.doi.org/10.1038/ki.2013.251] [PMID: 24172728]

[49] Smith KD. Toll-like receptors in kidney disease. Curr Opin Nephrol Hypertens 2009; 18(3): 189-96. [http://dx.doi.org/10.1097/MNH.0b013e32832a1d5f] [PMID: 19352178]

[50] Anders HJ, Schaefer L. Beyond tissue injury-damage-associated molecular patterns, toll-like receptors, and inflammasomes also drive regeneration and fibrosis. J Am Soc Nephrol 2014; 25(7): 1387-400. [http://dx.doi.org/10.1681/ASN.2014010117] [PMID: 24762401]

[51] Meng XM, Nikolic-Paterson DJ, Lan HY. Inflammatory processes in renal fibrosis. Nat Rev Nephrol 2014; 10(9): 493-503. [http://dx.doi.org/10.1038/nrneph.2014.114] [PMID: 24981817]

[52] Vilaysane A, Chun J, Seamone ME, et al. The NLRP3 inflammasome promotes renal inflammation and contributes to CKD. J Am Soc Nephrol 2010; 21(10): 1732-44.

[http://dx.doi.org/10.1681/ASN.2010020143] [PMID: 20688930]

[53] Chen K, Zhang J, Zhang W, et al. ATP-P2X4 signaling mediates NLRP3 inflammasome activation: a novel pathway of diabetic nephropathy. Int J Biochem Cell Biol 2013; 45(5): 932-43. [http://dx.doi.org/10.1016/j.biocel.2013.02.009] [PMID: 23434541]

[54] Fang L, Xie D, Wu X, Cao H, Su W, Yang J. Involvement of endoplasmic reticulum stress in albuminuria induced inflammasome activation in renal proximal tubular cells. PLoS One 2013; 8(8): e72344. [http://dx.doi.org/10.1371/journal.pone.0072344] [PMID: 23977286]

[55] Martin-Rodriguez S, Caballo C, Gutierrez G, et al. TLR4 and NALP3 inflammasome in the development of endothelial dysfunction in uraemia. Eur J Clin Invest 2015; 45(2): 160-9.

[http://dx.doi.org/10.1111/eci.12392] [PMID: 25496217]

[56] Matsumoto K, Kanmatsuse K. Elevated interleukin-18 levels in the urine of nephrotic patients. Nephron 2001; 88(4): 334-9. [http://dx.doi.org/10.1159/000046017] [PMID: 11474228]

[57] Matsumoto K, Kanmatsuse K. Increased urinary excretion of interleukin-17 in nephrotic patients. Nephron 2002; 91(2): 243-9. [http://dx.doi.org/10.1159/000058399] [PMID: 12053060]

[58] Lonnemann G, Novick D, Rubinstein M, Dinarello CA. Interleukin-18, interleukin-18 binding protein and impaired production of interferongamma in chronic renal failure. Clin Nephrol 2003; 60(5): 327-34. [http://dx.doi.org/10.5414/CNP60327] [PMID: 14640238]

[59] Ortega LM, Fornoni A. Role of cytokines in the pathogenesis of acute and chronic kidney disease, glomerulonephritis, and end-stage kidney disease. Int J Interfer Cytok Mediat Res 2010; 2: 49-62. [http://dx.doi.org/10.2147/IJICMR.S10111]

[60] Goicoechea M, de Vinuesa SG, Verdalles U, et al. Effect of allopurinol in chronic kidney disease progression and cardiovascular risk. Clin J Am Soc Nephrol 2010; 5(8): 1388-93.

[http://dx.doi.org/10.2215/CJN.01580210] [PMID: 20538833]

[61] Kao MP, Ang DS, Gandy SJ, et al. Allopurinol benefits left ventricular mass and endothelial dysfunction in chronic kidney disease. J Am Soc Nephrol 2011; 22(7): 1382-9. [http://dx.doi.org/10.1681/ASN.2010111185] [PMID: 21719783]

[62] Momeni A, Shahidi S, Seirafian S, Taheri S, Kheiri S. Effect of allopurinol in decreasing proteinuria in type 2 diabetic patients. Iran J Kidney Dis 2010; 4(2): 128-32. [PMID: 20404423]

[63] Sarris E, Bagiatudi G, Stavrianaki D, et al. Use of allopurinol in slowing the progression of chronic renal disease. Nephrol Dial Transplant 2007; 22: 28-61. [abstract]. [PMID: 17023494]

[64] Siu YP, Leung KT, Tong MK, Kwan TH. Use of allopurinol in slowing the progression of renal disease through its ability to lower serum uric acid level. Am J Kidney Dis 2006; 47(1): 51-9. [http://dx.doi.org/10.1053/j.ajkd.2005.10.006] [PMID: 16377385]

[65] Shi Y, Chen W, Jalal D, et al. Clinical outcome of hyperuricemia in IgA nephropathy: a retrospective cohort study and randomized controlled trial. Kidney Blood Press Res 2012; 35(3): 153-60. [http://dx.doi.org/10.1159/000331453] [PMID: 22116196]

[66] Gibson T, Rodgers V, Potter C, Simmonds HA. Allopurinol treatment and its effect on renal function in gout: a controlled study. Ann Rheum Dis 1982; 41(1): 59-65.

[http://dx.doi.org/10.1136/ard.41.1.59] [PMID: 7039523] 
[67] Kanbay M, Huddam B, Azak A, et al. A randomized study of allopurinol on endothelial function and estimated glomular filtration rate in asymptomatic hyperuricemic subjects with normal renal function. Clin J Am Soc Nephrol 2011; 6(8): $1887-94$. [http://dx.doi.org/10.2215/CJN.11451210] [PMID: 21784838]

[68] Bose B, Badve SV, Hiremath SS, et al. Effects of uric acid-lowering therapy on renal outcomes: a systematic review and meta-analysis. Nephrol Dial Transplant 2014; 29(2): 406-13. [http://dx.doi.org/10.1093/ndt/gft378] [PMID: 24042021]

[69] Badve SV, Brown F, Hawley CM, et al. Challenges of conducting a trial of uric-acid-lowering therapy in CKD. Nat Rev Nephrol 2011; 7(5): 295-300.

[http://dx.doi.org/10.1038/nrneph.2010.186] [PMID: 21321568]

[70] Jalal DI, Chonchol M, Chen W, Targher G. Uric acid as a target of therapy in CKD. Am J Kidney Dis 2013; 61(1): 134-46. [http://dx.doi.org/10.1053/j.ajkd.2012.07.021] [PMID: 23058478]

[71] Whelton A, Macdonald PA, Zhao L, Hunt B, Gunawardhana L. Renal function in gout: long-term treatment effects of febuxostat. J Clin Rheumatol 2011; 17(1): 7-13.

[http://dx.doi.org/10.1097/RHU.0b013e318204aab4] [PMID: 21169856]

[72] Miao Y, Ottenbros SA, Laverman GD, et al. Effect of a reduction in uric acid on renal outcomes during losartan treatment: a post hoc analysis of the reduction of endpoints in non-insulin-dependent diabetes mellitus with the Angiotensin II Antagonist Losartan Trial. Hypertension $2011 ; 58(1): 2-7$.

[http://dx.doi.org/10.1161/HYPERTENSIONAHA.111.171488] [PMID: 21632472]

[73] Kang DH, Nakagawa T, Feng L, et al. A role for uric acid in the progression of renal disease. J Am Soc Nephrol 2002; $13(12)$ : $2888-97$. [http://dx.doi.org/10.1097/01.ASN.0000034910.58454.FD] [PMID: 12444207]

[74] Dinarello CA, van der Meer JW. Treating inflammation by blocking interleukin-1 in humans. Semin Immunol 2013; 25(6): 469-84. [http://dx.doi.org/10.1016/j.smim.2013.10.008] [PMID: 24275598]

[75] Schlesinger N. Anti-interleukin-1 therapy in the management of gout. Curr Rheumatol Rep 2014; 16(2): $398-403$. [http://dx.doi.org/10.1007/s11926-013-0398-z] [PMID: 24407823]

[76] Kovesdy CP, Kalantar-Zadeh K. Novel targets and new potential: developments in the treatment of inflammation in chronic kidney disease. Expert Opin Investig Drugs 2008; 17(4): 451-67.

[http://dx.doi.org/10.1517/13543784.17.4.451] [PMID: 18363512]

[77] Goicoechea M, de Vinuesa GS, Verdalles U, et al. Allopurinol and progression of CKD and cardiovascular events: long-term follow-up of a randomized clinical trial. Am J Kidney Dis 2015; 65(4): 543-9. [http://dx.doi.org/10.1053/j.ajkd.2014.11.016] [PMID: 25595565]

[78] Turner CM, Arulkumaran N, Singer M, Unwin RJ, Tam FW. Is the inflammasome a potential therapeutic target in renal disease? BMC Nephrol 2014; 15: 21. [http://dx.doi.org/10.1186/1471-2369-15-21] [PMID: 24450291]

Received: April 18, $2015 \quad$ Revised: April 30, 2015 Accepted: April 30, 2015

(C) William F. Finn; Licensee Bentham Open.

This is an open access article licensed under the terms of the Creative Commons Attribution-Non-Commercial 4.0 International Public License (CC BY-NC 4.0) (https://creativecommons.org/licenses/by-nc/4.0/legalcode), which permits unrestricted, non-commercial use, distribution and reproduction in any medium, provided the work is properly cited. 